\title{
Editorial: Effects of Ice Loss on Marine Biodiversity
}

\author{
Katrin Linse ${ }^{1 *}$, Ilka Peeken ${ }^{2}$ and Anne Helene Solberg Tandberg ${ }^{3}$ \\ ${ }^{1}$ Biodiversity, Evolution \& Adaptation Team, British Antarctic Survey, Cambridge, United Kingdom, ${ }^{2}$ Polar Biological \\ Oceanography, Helmholtz Centre for Polar and Marine Research, Alfred Wegener Institute, Bremerhaven, Germany, ${ }^{3}$ Natural \\ History Department, University Museum, University of Bergen, Bergen, Norway
}

Keywords: zooplankton, phytoplankton, zoobenthos, meiofauna, in-situ habitat images

\section{Editorial on the Research Topic}

\section{Effects of Ice Loss on Marine Biodiversity}

The Arctic and Antarctic oceans are undergoing changes in the extent of their sea-ice and ice-shelves (IPCC, in press). These have important impacts on the biodiversity, structure, and function of sea ice biota, pelagic and benthic communities, and will change the composition, distribution, and productivity of all species in these ecosystems (Constable et al., 2014; Lannuzel et al., 2020). Decreasing Arctic sea ice has led to a northwards shift in phytoplankton distributions (Nöthig et al., 2015; Metfies et al., 2016) and phytoplankton blooms were discovered in autumn (Ardyna et al., 2014). Shifts were also observed in the vertical and horizontal distributions of zooplankton communities (Wassmann et al., 2015). In the Antarctic, gigantic icebergs have calved from ice shelves and in some cases, entire ice shelves have collapsed enabling sunlight and currents to reach the underlying benthic communities and providing new space for pelagic ecosystems (e.g., Vernet et al., 2019). The benthic habitats and their faunal inhabitants under floating Antarctic ice shelves are among the least known marine communities on Earth.

This Research Topic aimed to address all aspects of marine biodiversity science that introduce new knowledge to improve our understanding of the effects ice loss (sea ice and ice shelf) has on the pelagic and benthic communities in the polar oceans (Figure 1). Contributions were delivered by 61 participating authors providing up-to-date information on the species richness and biogeographic responses in marine biodiversity adapted to ice-covered environments, on their phylogeographic relationships and how they affect biogeochemical cycles, on the status of the effects of ice loss on marine biogeochemistry and biodiversity on regional and global scales, on how feedbacks and controls could change these systems and ultimately, on what new conditions might be present in these regions on decadal and longer time scales.

Reduction of sea-ice in the Arctic resulted in a massive loss of the previous typical multiyear ice, with a reduction of biodiversity of the sea-ice associated protists (Hop et al., 2021) and an increase of primary production (Arrigo and Van Dijken, 2015). North of Svalbard Ehrlich et al. show loss in biodiversity for the sympagic meiofauna, with nematodes totally absent and only a low number of flatworms. In addition, hardly any sympagic amphipods were present, suggesting the strong connectivity of these organisms with multiyear ice. A study of lipid biomarkers gives further insight in the transfer of sea-ice derived carbon for higher trophic levels. While Kohlbach et al. (2016) demonstrated a strong dependence of the sympagic and pelagic organisms on sea-ice derived carbon in the Central Arctic, Kohlbach et al. suggest that for Barents Sea amphipods this is only a surplus food source. Calanoid copepods already shifted their food demand entirely on pelagic resources and thus might have already adapted to the changing sea ice conditions in this region. By applying high-throughput amplicon sequencing, Kalenitchenko et al. show a distinct difference of protists diversity between the Arctic Ocean and the Central Arctic suggesting a low connectivity 


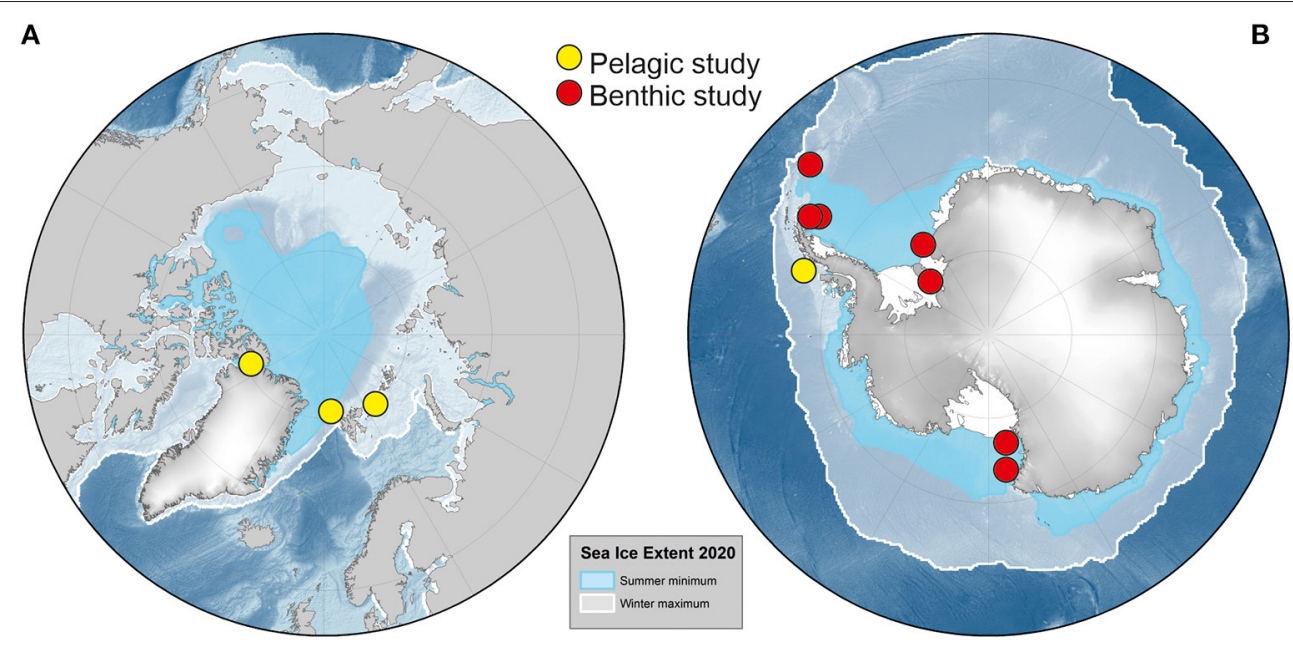

B

Southern Ocean. The maps are drawn to $55^{\circ}$ latitude. Sea ice extent data are from https://nsidc.org/cryosphere/sotc/sea_ice.html.

between these regions and imply that the ongoing changes in sea ice cover will not result in a high productive Nares Strait ecosystem.

Moving to the Antarctic, particularly the western Antarctic Peninsula is the key region, where rapid sea ice loss has been reported with major consequences for the ecosystem (Constable et al., 2014). By applying whole community metatranscriptomic together with lipidomics Bowman et al. analyzed how lipid production and utilization was influenced by changing light conditions. They show an intrinsic adaptation behind various pelagic species, implying future changes in the phytoplankton composition, and the production of lipid-rich food sources with the ongoing change of the sea ice cover along the western Antarctic Peninsula.

Effects of changes and status-quo of benthic communities and their biodiversity were studied in the Antarctic Peninsula, Weddell, and Ross seas. The Prince Gustav Channel area had been influenced by the break-up of the Prince Gustav ice shelf, retreating glaciers, and changes in sea-ice cover but its benthic biodiversity had been never assessed. The meiobenthic and nematode communities, analyzed by Pantó et al. using metabarcoding and environmental proxy characterization, revealed high densities at all depths based on availability of fresh organic sedimentary matter. As shown by Di Franco et al. also abundance and community structure of macrobenthic peracarids were affected by length of sea ice cover and associated blooms of the primary producers. Drennan et al. reported a diverse and spatially heterogenous annelid fauna, including wide-spread, circum-Antarctic species as well as yet unnamed species in an area with dynamic recent glacial history. The in-situ habitat heterogeneity in the Prince Gustav Channel was illustrated by Almond et al. showing that locations previously covered by the ice shelf held distinct and unique communities. In the Ross Sea, Cummings et al. investigating macro-infaunal and mega-epifaunal benthos showed that organic seabed fluxes and sea ice cover were important for the community structure.

Describing and understanding the marine communities and their biodiversity under the floating ice shelves is still a gap in our knowledge, as these communities are mostly accessible to study after the collapse. Multidisciplinary collaborations with geological and glaciological scientists using shelf ice core bore holes gave a first glimpse into these unknown ecosystems as reviewed by Griffiths et al. who also presented the first record of hard rock suspension feeder community hundreds of kilometers away from the open ocean. These unique, unstudied ecosystems, like under the Filchner-Ronne Ice shelf, are under future climate threads as Naughten et al. (2021) are predicting significant changes in the oceanographic settings.

This volume provides a brief indication of the current state of the art and indicates some of the pressing issues and questions related to ice and biodiversity loss in the Polar Regions. We, the editors, hope that this Research Topic will form the basis of further discussion and will foster future cross-polar region research in the effects of ice loss on marine biodiversity.

\section{AUTHOR CONTRIBUTIONS}

KL wrote the first draft of the manuscript KL, IP, and AT wrote sections of the manuscript. KL drafted the figure. All authors contributed to manuscript, read, and approved the submitted version.

\section{ACKNOWLEDGMENTS}

We thank our authors for submitting their research to our topic. We are especially grateful to the reviewers who returned their comments within the requested timeline. Special thanks to Huw J. Griffiths for providing the maps for the figure. 


\section{REFERENCES}

Ardyna, M., Babin, M., Gosselin, M., Devred, E., Rainville, L., and Tremblay, J. E. (2014). Recent Arctic Ocean sea ice loss triggers novel fall phytoplankton blooms. Geophys. Res. Lett. 41, 6207-6212. doi: 10.1002/2014GL061047

Arrigo, K. R., and Van Dijken, G. L. (2015). Continued increases in Arctic Ocean primary production. Prog. Oceanogr. 136, 60-70. doi: 10.1016/j.pocean.2015.05.002

Constable, A. J., Melbourne-Thomas, J., Corney, S. P., Arrigo, K. R., Barbraud, C., Barnes, D. K. A., et al. (2014). Climate change and Southern Ocean ecosystems I: how changes in physical habitats directly affect marine biota. Glob. Change Biol. 20, 3004-3025. doi: 10.1111/gcb.12623

Hop, H., Wold, A., Meyer, A., Bailey, A., Hatlebakk, M., Kwasniewski, S., et al. (2021). Winter-spring development of the zooplankton community below sea ice in the Arctic Ocean. Front. Mar. Sci. 9, 1-21. doi: $10.3389 /$ fmars.2021.609480

IPCC (in press). "Climate change 2021: the physical science basis," in Contribution of Working Group I to the Sixth Assessment Report of the Intergovernmental Panel on Climate Change, eds V. Masson-Delmotte, P. Zhai, A. Pirani, S. L. Connors, C. Péan, S. Berger, N. Caud, Y. Chen, L. Goldfarb, M. I. Gomis, M. Huang, K. Leitzell, E. Lonnoy, J. B. R. Matthews, T. K. Maycock, T. Waterfield, O. Yelekçi, R. Yu, and B. Zhou (Cambridge University Press).

Kohlbach, D., Graeve, M., Lange, B. A., David, C., Peeken, I., and Flores, H. (2016). The importance of ice algae-produced carbon in the central Arctic Ocean ecosystem: food web relationships revealed by lipid and stable isotope analyses. Limnol. Oceanogr. 61, 2027-2044. doi: 10.1002/lno.10351

Lannuzel, D., Tedesco, L., Van Leeuwe, M., Campbell, K., Flores, H., Delille, B., et al. (2020). The future of Arctic sea-ice biogeochemistry and ice-associated ecosystems. Nat. Clim. Change 10, 983-992. doi: 10.1038/s41558-020-00940-4

Metfies, K., Von Appen, W. J., Kilias, E., Nicolaus, A., and Nothig, E. M. (2016). Biogeography and photosynthetic biomass of arctic marine pico-eukaroytes during summer of the record sea ice minimum 2012. PLoS ONE 11:e0148512. doi: 10.1371 /journal.pone. 0148512
Naughten, K. A., De Rydt, J., Rosier, S. H. R., Jenkins, A., Holland, P. R., and Ridley, J. K. (2021). Two-timescale response of a large Antarctic ice shelf to climate change. Nat. Commun. 12:1991. doi: 10.1038/s41467-02122259-0

Nöthig, E. M., Bracher, A., Engel, A., Metfies, K., Niehoff, B., Peeken, I., et al. (2015). Summertime plankton ecology in Fram Strait - a compilation of longand short-term observations. Polar Res. 34:23349. doi: 10.3402/polar.v34.23349

Vernet, M., Geibert, W., Hoppema, M., Brown, P. J., Haas, C., Hellmer, H. H., et al. (2019). The Weddell Gyre, Southern Ocean: present knowledge and future challenges. Rev. Geophys. 57, 623-708. doi: 10.1029/2018RG000604

Wassmann, P., Kosobokova, K. N., Slagstad, D., Drinkvvater, K. F., Hoperoft, R. R., Moore, S. E., et al. (2015). The contiguous domains of Arctic Ocean advection: trails of life and death. Prog. Oceanogr. 139, 42-65. doi: 10.1016/j.pocean.2015.06.011

Conflict of Interest: The authors declare that the research was conducted in the absence of any commercial or financial relationships that could be construed as a potential conflict of interest.

Publisher's Note: All claims expressed in this article are solely those of the authors and do not necessarily represent those of their affiliated organizations, or those of the publisher, the editors and the reviewers. Any product that may be evaluated in this article, or claim that may be made by its manufacturer, is not guaranteed or endorsed by the publisher.

Copyright $\odot 2021$ Linse, Peeken and Tandberg. This is an open-access article distributed under the terms of the Creative Commons Attribution License (CC BY). The use, distribution or reproduction in other forums is permitted, provided the original author(s) and the copyright owner(s) are credited and that the original publication in this journal is cited, in accordance with accepted academic practice. No use, distribution or reproduction is permitted which does not comply with these terms. 